\title{
INSTITUTIONAL FRAMEWORKS \\ AND LABOR MARKET PERFORMANCE
}

\author{
Friedrich Buttler, Wolfgang Franz, Ronald Schettkat and \\ David Soskice
}

\section{INTRODUCTION}

While Germans are fascinated by tremendous U.S. job growth during the last decades, Americans are equally captivated by income growth and social stability in Germany. In Europe the United States is often regarded as the example of the jobcreating power of unfettered markets, whereas Germany is seen as an example of an overregulated economy and an especially overregulated labor market, both of which have prevented employment from growing. The suggestion to European politicians is to deregulate their economies and become like the U.S. but Americans themselves are worried about income stagnation and dispersion, about the trade deficit, health insurance coverage, and the instability of employment.

The list of institutions that were alleged to cause inefficient labor markets in Europe (Giersch 1985) is long: Collective bargaining, sticky wages and a distorted wage structure reduced the allocative efficiency of labor markets; strong unions increased insider power, kept wages high and excluded outsiders; legislation extended workers' representation and participation in decision-making processes; employment protection laws made dismissals not impossible but very costly, leading employers to be reluctant in hiring; unemployment benefits - replacement ratios as well as the duration of eligibility - have been alleged to be a major distortion of the incentive structure which led to inefficient searches, inefficient skill adjustments, mismatches, and persistent long-term unemployment. Deregulation to (re-) achieve an undistorted incentive structure was (and is) the clear policy advice following from this analysis. Searching for opportunities to deregulate became one of the main tasks of politicians, and in the UK and the U.S. such deregulation was probably most widely applied. In Germany, the government created a commission for deregulation whose task was to target areas of public intervention and justify their deregulation (see Donges 1992). However, recent economic and social problems in the U.S. and the UK produced doubts about the efficiency of this strategy. 
Americans look to Japan and Germany when developing proposals to increase the efficiency of their economy. The process of European unification received substantial attention in the U.S. (see Ulman et al. 1993). Japanese-style work organization and employment stability; German-type apprenticeship systems, works councils, and unions attracted the interest of American economists and politicians. The Clinton administration aims at introducing new labor market and social institutions. "The philosophy here is very simple: Unless people have the security they need to adapt to future, I believe they will seek security by trying to preserve the past" (Robert Reich, speech 1993).

This raises some questions. Are the institutional features of the industrialized economies converging? Can the most favorable institutional arrangements of one country simply be transplanted into another country's institutional framework (see Chapter 4)? To what extent do these policy proposals rely on real world factors not included in theoretical models, which can completely change how particular institutional arrangements will work (see Chapter 9)?

Critics of the wel fare state tended to overemphasize economic efficiency. Welfare state programs also try to achieve other goals such as equality. To evaluate such programs one must undertake a cost-benefit analysis. "In a cost-benefit framework, the net social return from transfer programs is positive if the social value of the increase in security among individual citizens is greater than the social value of any lost growth or productivity. Simply showing that programs have distortionary effects or inefficiency costs to the economy is not sufficient to argue against them" (Blank and Freeman 1994).

Although welfare institutions are designed to achieve various purposes, they may nevertheless support the search for economic efficiency. Regulations are not necessarily "politics against the market," but they can very well complement markets. If natural rigidities are taken into account, and if dynamic efficiency rather than allocative efficiency in a static framework of analysis is used for the evaluation of the impact of instirutions, the conclusion may look quite different from results obtained with static analysis. That is to say that the real world should not be evaluated with reference to the first best solution, but that second or third best may be the appropriate reference for the evaluation of institutions. Natural rigidities should not simply be taken as market imperfections but as features which are part of the way markets function (Gordon 1990). Given the possibility of different paths of developments one may have, for example, a low-skill labor market equilibrium as well as a high-skill labor market equilibrium. Which of the two equilibria can be reached depends substantially on the institutional framework (Finegold and Soskice 1989; Soskice 1993). That is to say, careful evaluations need to take the institutional frameworks into account rather than to evaluate specific regulations in an isolated way.

\section{TRENDS IN U.S. AND GERMAN LABOR MARKETS}

The trends in unemployment of the two economies are probably surprising: While the unemployment rate in the United States declined from about 5 percent in the 
early 1960's to 3.5 percent in 1968-1969, Germany experienced virtually no unemployment until 1973 (Figure 1.1 and Table 1.1, first columns). From 1960 to 1972 the average unemployment rate was below 1.0 percent in every year except the recession period of 1967-1968, when the rate increased to 1.8 percent. The German labor market was characterized by excess demand which was partly accommodated through the employment of "guest workers," i.e., foreign workers, which increased from 1.3 percent to 10 percent of total employment between 1960 and 1973.

The spurt in the German unemployment rate began in 1974. While unemployment in the United States evolved more cyclically, with peaks in 1975 and 1982-1983, Germany experienced a rise in unemployment in two steps, but with little decline between 1975-1980 and 1983-1988. In the period 1983-1990 the official German unemployment rate was above that in the U.S., which would not have been so remarkable except for the stark contrast in the opposite direction during the 1960's and 1970's. However, looking at adjusted German unemployment figures (Table 1.1, column 2), which are comparable to U.S. definitions, reveals that between 1984 and 1990 unemployment rates do not differ as much as suggested by the official German figures. In fact, in some years both numbers are virtually identical. "Low" unemployment in the U.S. was "high" unemployment in Germany. But nevertheless, employment trends differed substantially (columns 6 and 7 in Table 1.1) between the two economies.

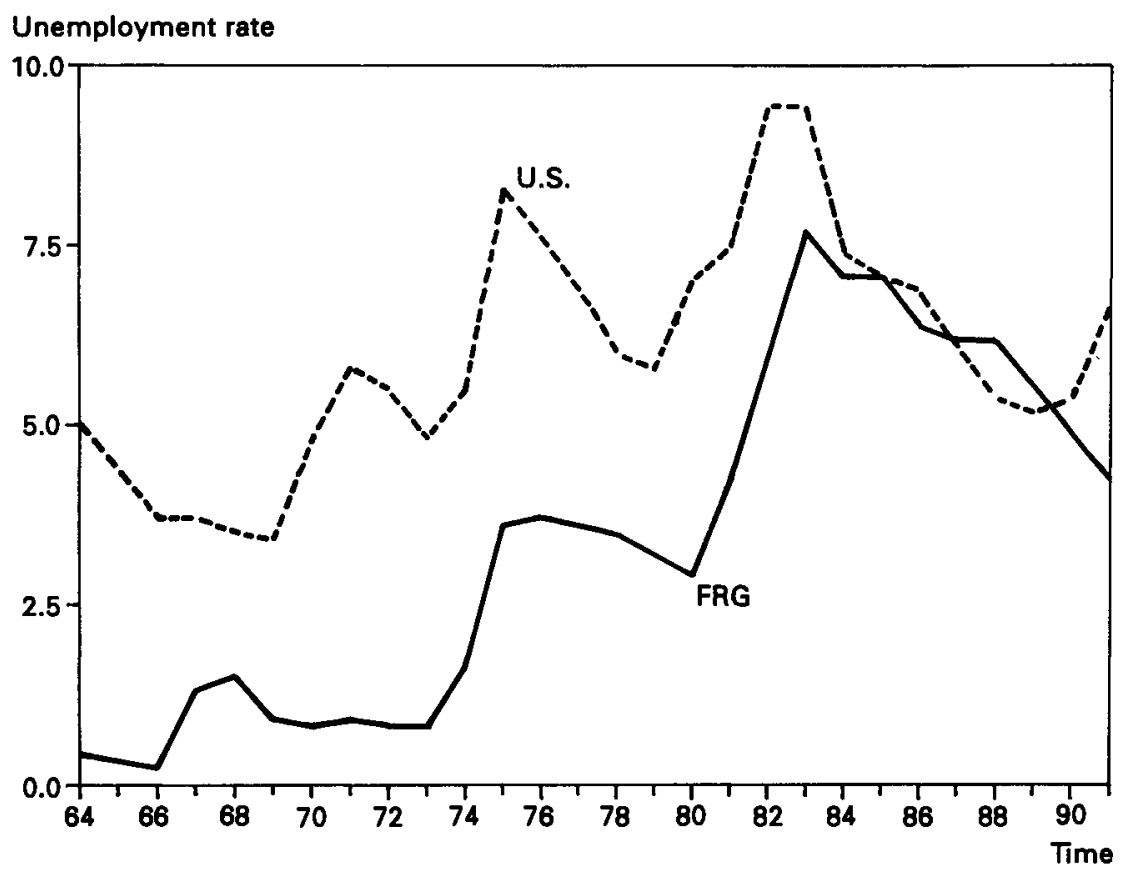

Figure 1.1 Unemployment Rates in Germany and the United States Source. OECD (1993) Economic Outlook, 53: 218 


\section{F. BUTTLER, W. FRANZ, R. SCHETTKAT, D. SOSKICE}

Table 1.1 shows also the high and growing share of long-term unemployment in Germany, compared to its small share in the U.S. Long-term unemployed persons constitute a major challenge to labor market policies because older people and those with health deficiencies are considerably overrepresented in this group. The reason for this development of high long-term unemployment is that the probability of a transition to employment decreases with the duration of unemployment because unsuccessful job seekers become discouraged and/or firms use unemployment as a screening device in order to identify the unknown productivity of an applicant.

Note that the employment series in Table 1.1 refer to the private nonfarm sector. The reason for this restriction is that employment in the public sector is subject to country-specific regulations concerning protection against dismissals and the like. Moreover, employment series in the agricultural sector include (unpaid) family workers, which renders time series data on hours, wages, and productivity less reliable. The rise in employment in the U.S. amounts to 76 percent growth over the past three decades. This growth cannot be explained by the high and increasing share

Table 1.I Summary Measures of Unemployment, Employment, and Hours

\begin{tabular}{|c|c|c|c|c|c|c|c|c|c|}
\hline \multirow{3}{*}{$\begin{array}{l}\text { Average } \\
\text { Over } \\
\text { Interval }\end{array}$} & \multicolumn{3}{|c|}{$\begin{array}{c}\text { Unemployment } \\
\text { Rate }\end{array}$} & \multicolumn{2}{|c|}{$\begin{array}{c}\text { Share } \\
\text { of Long-Term } \\
\text { Unemployed }\end{array}$} & \multicolumn{2}{|c|}{$\begin{array}{l}\text { Employed } \\
\text { Persons } \\
\text { (millions) }\end{array}$} & \multicolumn{2}{|c|}{$\begin{array}{l}\text { Annual } \\
\text { Hours per } \\
\text { Worker }\end{array}$} \\
\hline & $\begin{array}{c}F R G \\
\text { official }\end{array}$ & $\begin{array}{c}F R G \\
\text { adjusted }\end{array}$ & US & $F R G$ & $U S$ & $F R G$ & $U S$ & $F R G$ & $U S$ \\
\hline & $I$ & 2 & 3 & 4 & 5 & 6 & 7 & 8 & 9 \\
\hline $1961-1964$ & 0.6 & 0.4 & 5.8 & n.a. & n.a. & 20.2 & 62.5 & 2,081 & 1,799 \\
\hline $1965-1969$ & 1.0 & 0.7 & 3.8 & 9.1 & $2.1^{2}$ & 20.2 & 70.5 & 2,003 & 1,816 \\
\hline $1970-1973$ & 0.8 & 0.6 & 5.4 & 7.1 & 3.5 & 20.8 & 77.9 & 1,909 & 1,796 \\
\hline $1974-1979$ & 3.5 & 3.0 & 6.8 & 15.3 & 5.5 & 20.1 & 88.0 & 1,803 & 1,759 \\
\hline $1980-1984$ & 6.0 & 5.3 & 8.3 & 23.2 & 8.9 & 20.3 & 97.6 & 1,734 & 1,722 \\
\hline $1985-1990$ & 7.3 & 6.2 & 6.1 & 35.8 & 7.5 & 20.8 & 110.1 & 1,675 & 1,709 \\
\hline
\end{tabular}

Sources. Adjusted unemployment rate: Abraham and Houseman 1993; other sources see below. (For column notes below - numbers in brackets refer to citations in 'Notes' below.)

Sources. [1] Official News of the Federal Labor Office, Germany. [2] German Institute of Economic Research, quarterly national accounts. [3] IFO-Institute, Munich. [4] Economic Report of the Presidenr, February 1992. [5] Survey of Current Business. [6] Economic Indicators. [7] Bureau of Labor Statistics. [8] Abraham and Houseman (1993: 49).

Note. 2 refers to 1967-69 only; long-term unemployment is defined as unemployment lasting longer than 12 months.

Notes for Germany and U.S. by column number (); numbered sources appear in brackets [] at the end of each note, see Table 1.2 .

Germany (1) Registered unemployed persons as a percentage of civilian labor force (including selfemployed) [1]. (2) Adjusted to approximate U.S. concepts [8]. (4) Percentage of unemployed more than one year. Figures prior to 1966 are not available [1]. (6) Including self-employed persons; private nonfarm secror [2]. (8) Per year; aggregate economy; including self-employed persons [2].

U.S. (3) Unemployed persons as a percentage of civilian labor force [7]. (5) Percentage of unemployed more than one year. Figures prior to 1967 are not available [7]. (7) Including self-employed persons; private non-farm sector [4]. (9) Per year; aggregate economy; including self-employed persons [5]. 
of part-time employment in the U.S. but is rather caused by the higher employment elasticity of economic growth in the U.S. (Schettkat 1992). It is remarkable that American job growth is visible over the whole time period and not limited to the 1980 's as sometimes assumed by proponents of the "American job machine."

Another difference between American and German labor market development is the decline in hours worked per employee as evidenced by columns 8 and 9 of Table 1.1. Taken at face value, in Germany, annual hours per employee have fallen from 16 percent above the U.S. level in the beginning of the 1960's to 2 percent below by the end of the 1980's (see Bell and Freeman in this volume). To a major extent this is due to a specific aspect of German wage determination totally absent in the U.S., namely a perceived trade-off between wage increases and negotiated reductions in weekly working hours.

In view of the unfortunate developments of the German labor market in the 1980 's, the unions urged for reductions in working time in order to redistribute the burden of unemployment. The metal industry took the lead when it pushed working time reduction through in the strike of the summer of 1984, which was one of the longest and most costly in recent German history. However, given the loss of international competitiveness of the German economy and the considerable difficulties stemming from the financial burdens of German unification, there are a growing number of voices in the political arena calling for a reversal of the tremendous reduction of working time. On the other hand, work-sharing has been proposed and implemented as a measure to prevent unemployment.

In a recent econometric study on American and German wage and price determination, Franz and Gordon (1993) find that during the 1970's and 1980's in Germany there emerged a growing discrepancy between the labor market and industrial capacity so that the unemployment rate consistent with the constantinflation urilization rate of capacity increased sharply, while in the U.S. this rate was fairly stable. In addition there is empirical evidence that the relationship between unemployment and vacancies, the so-called Beveridge curve, has shifted outwards, which may indicate higher mismatch in the labor market (see e.g., Franz 1991 and Chapter 13 in this volume).

Table 1.2 displays data on wage and price changes, productivity growth, and the rate of capacity utilization (displayed as the deviation from the 1960-1990 mean rate). Wage and price changes in the U.S. decelerated markedly in the second half of the 1980's despite higher capacity utilization than in the first half, which may be explained by lagged wage and price adjustment to earlier low utilization, as well as by lower oil prices. The figures for Germany in the 1980's show relarively low and stable wage and price inflation with relatively high capacity utilization. As a summary measure of the development of wages, prices and productivity columns 9 and 10 in Table 1.2 show the rime pattern of labor's share of income for both countries, i.e., gross labor compensation as a share of national income. The German share has fluctuated around its mean of 67.8 percent bur shows no trend, i.e., it is roughly equal to its mean in both 1961-1964 and 1985-1990. In contrast the U.S. labor share exhibits a one-time jump in the early 1970's, with little movement in other 
Table 1.2 Summaty Measures of Wages, Prices, Productivity, and Labor's Share (annual percentage growth rates).

\begin{tabular}{|c|c|c|c|c|c|c|c|c|c|c|}
\hline \multirow{3}{*}{$\begin{array}{l}\text { Average } \\
\text { Over } \\
\text { Interval }\end{array}$} & \multicolumn{2}{|c|}{$\begin{array}{l}\text { Nominal } \\
\text { Wage } \\
\text { Growth }\end{array}$} & \multicolumn{2}{|c|}{$\begin{array}{c}\text { Growth } \\
\text { Rate of } \\
\text { GDP } \\
\text { Deflator }\end{array}$} & \multicolumn{2}{|c|}{$\begin{array}{c}\text { Growth Rate } \\
\text { of } \\
\text { Real Product } \\
\text { Wage }\end{array}$} & \multicolumn{2}{|c|}{$\begin{array}{c}\text { Actual } \\
\text { Productivity } \\
\text { Growth }\end{array}$} & \multicolumn{2}{|c|}{$\begin{array}{c}\text { Labor's } \\
\text { Share }\end{array}$} \\
\hline & $F R G$ & US & $F R G$ & $U S$ & $F R G$ & US & $F R G$ & US & $F R G$ & US \\
\hline & 1 & 2 & 3 & 4 & 5 & 6 & 7 & 8 & 9 & 10 \\
\hline $1961-1964$ & 9.4 & 3.3 & 3.6 & 1.0 & 5.8 & 2.3 & 4.9 & 3.4 & 67.6 & 69.0 \\
\hline $1965-1969$ & 7.3 & 5.3 & 2.7 & 2.9 & 4.6 & 2.4 & 5.2 & 1.8 & 63.2 & 70.0 \\
\hline $1970-1973$ & 12.4 & 7.0 & 6.3 & 3.8 & 6.1 & 3.2 & 4.6 & 2.3 & 66.9 & 73.3 \\
\hline $1974-1979$ & 7.9 & 8.2 & 4.5 & 6.6 & 3.4 & 1.6 & 3.7 & 0.6 & 69.8 & 73.5 \\
\hline $1980-1984$ & 5.0 & 7.3 & 3.9 & 6.3 & 1.1 & 1.0 & 1.6 & 0.9 & 71.5 & 74.6 \\
\hline $1985-1990$ & 4.3 & 4.1 & 2.5 & 3.7 & 1.8 & 0.4 & 2.4 & 0.6 & 67.9 & 73.2 \\
\hline
\end{tabular}

Sources: [1] Official News of the Federal Labor Office, Germany. [2] German Institure of Economic Research, quarterly national accounts. [3] IFO-Institute, Munich. [4] Economic Report of the President, February 1992. [5] Survey of Current Business. [6] Economic Indicators. [7] Bureau of Labor Statistics. [8] Abraham and Houseman (1993: 49).

Notes. Nores appear in column number (); numbered sources appear in brackets [].

Germany (1) Hourly nominal wage cost including employer's contributions to social security; private nonfarm sector [2]. (3) Private nonfarm sector [2]. (5) $=(1)-(3)$. (7) Real value added per hour worked, $1985=100$, privare nonfarm sector [2]. (9) Unadjusted labor's share as displayed in the national accounts, i.e., total wage bill divided by national income; aggregate economy [2].

U.S. (2) Employment cost index linked to average hourly earnings index times compensation of employees divided by wages and salaries. Includes employer costs for employee benefits; private nonfarm sector [5] and [7]. (4) Private nonfarm sector [5]. (6) $=(2)-(4)$. (8) Output per hour, private nonfarm business sector [7]. (10) Definition same as for Germany [4].

periods. Given the widespread characterization of the German labor movement as strong and the American as weak, it is clearly surprising to find that the German labor share of income declined much more in the late 1980's than did the American.

Employment developments are one but not the only indicator of economic success. For example, the enormous job growth in the U.S. may be paid for by inefficiencies, that is by low productivity growth and hence income stagnation (Freeman 1988b). Germany, on the other hand, experienced high rates of productivity growth (Figure 1.2) which were in part made possible by a "lean labor force," that is low labor force participation. Productivity is measured by output per hour worked and this may be an incomplete measure, if high productivity growth is achieved by the exclusion of less productive workers or by the exclusion of activities with low productivity, like many services. It may well be that high productivity growth-the efficiency of the employed workers-is paid for by a loss in less efficient production. Therefore, income per capita of the working age population may be a more appropriate measure for the comparison of the overall economic performance between the U.S. and German economies. Indeed, the difference in productivity growth between the U.S. 

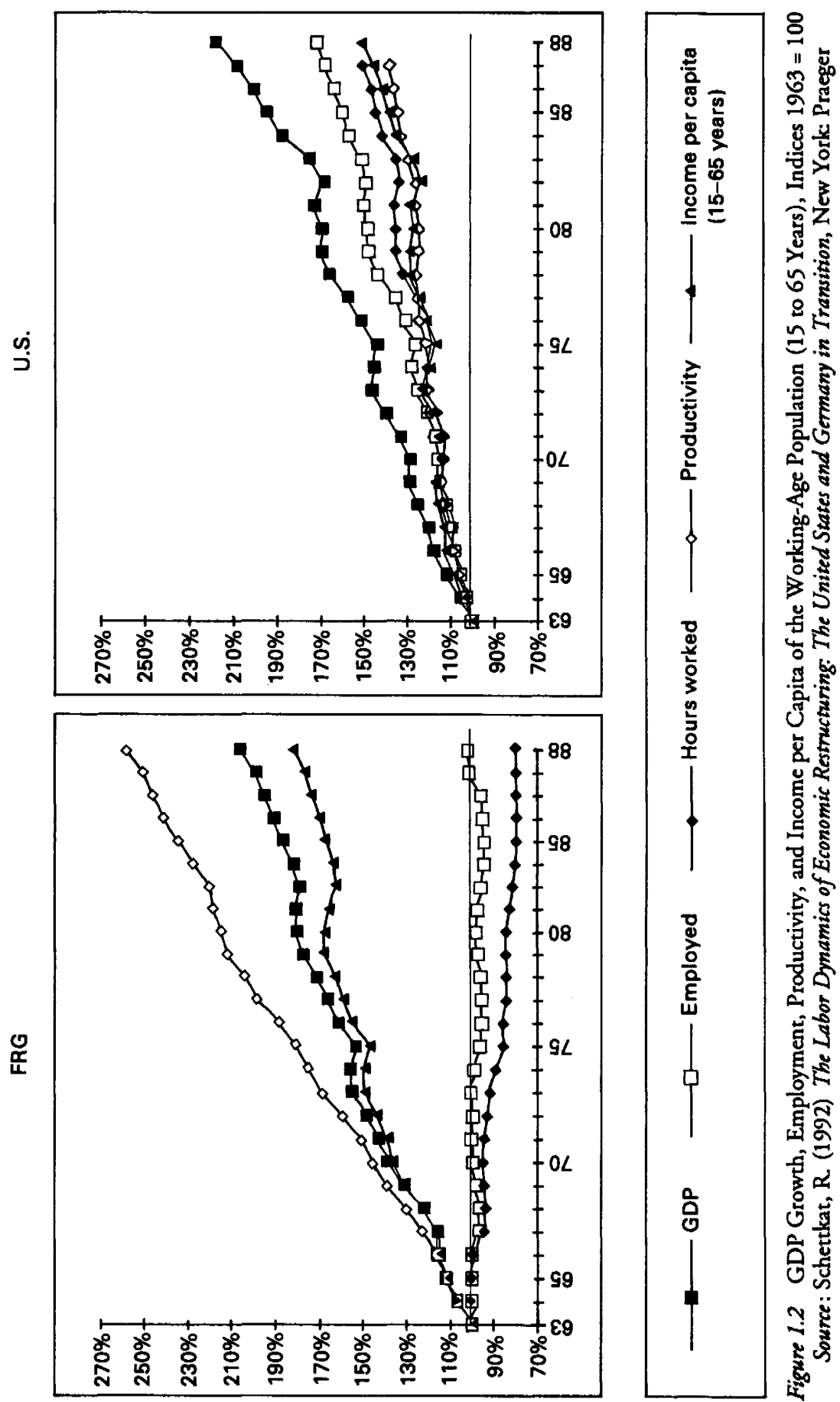
and Germany has been much higher than the difference in growth of income per capita indicating the greater importance of income transfers in Germany.

Although the U.S. experienced, withour doubt, more employment growth than Germany, the view that a sclerotic German labor market is not able to reallocate labor between industries is certainly mistaken. On the contrary, the German labor market managed substantial reallocation of labor with stagnating overall employment so that some industries were expanding while others were shrinking simultaneously (Table 1.3). Structural change in the U.S., on the other hand, took place by diverging but positive employment growth rates (Appelbaum and Schettkat 1990, 1993). Spurred by the tremendous increase in demand after the unification of the two Germanies the West German economy added 1.8 million jobs between 1990 and 1992. This hardly supports the view that the sclerotic German economy is unable to increase employment.

\section{REGULATION AND DEREGULATION: THE CHANGING VIEW ON INSTITUTIONS IN ECONOMICS}

Microeconomic analysis of the functioning of institutions along the lines of the new institutionalism, as well as research on innovation processes, produced insights into natural rigidities. Contract theory (Coase 1937; Williamson et al 1975) emphasizes the costs of transactions and suggests that the choice of institutions should be looked at as an optimization between market and nonmarket (hierarchical) transactions. Neither market nor nonmarket transactions are costless. Market transactions produce costs for searching, contracting etc., nonmarket transactions produce costs for personnel, negotiations etc. However, an important difference is that market transactions-at least in their pure sense-are short-term oriented (spot market) whereas the latter are always long-term oriented. The latter therefore reduce short-term flexibility but may improve long-term flexibility (Buttler 1987). Of course, stability (long-term contracting) reduces the ability to react to temporary shocks, but on the other hand, higher stability opens up completely new and different paths of development. There may not only be a difference between short-run and long-run optimization but there may also be differences in what can actually be achieved. That is to say that institutions not only influence the cost side but that they also influence output, quantitatively as well as qualitatively.

Research on innovation processes (Rosenberg 1982; Nelson and Winter 1982; C. Freeman 1989), for example, show that in a technological dynamic environment, spotmarket transactions may produce prohibitive costs and stifle innovation. Long-term relationships are required to engage in innovation processes with uncertain outcomes. Employment security, for example, may be necessary to ensure workers' cooperation for productivity improvements. Indeed, insiders get preferred access to new technology, promoting employment security in more innovative industries (Schettkat 1989). However, there are also other reasons for stable employment. The great bulk of working rules cannot be codified, therefore tacit knowledge embodied in the firms' employees as well as in the organization become important (David 1975). 


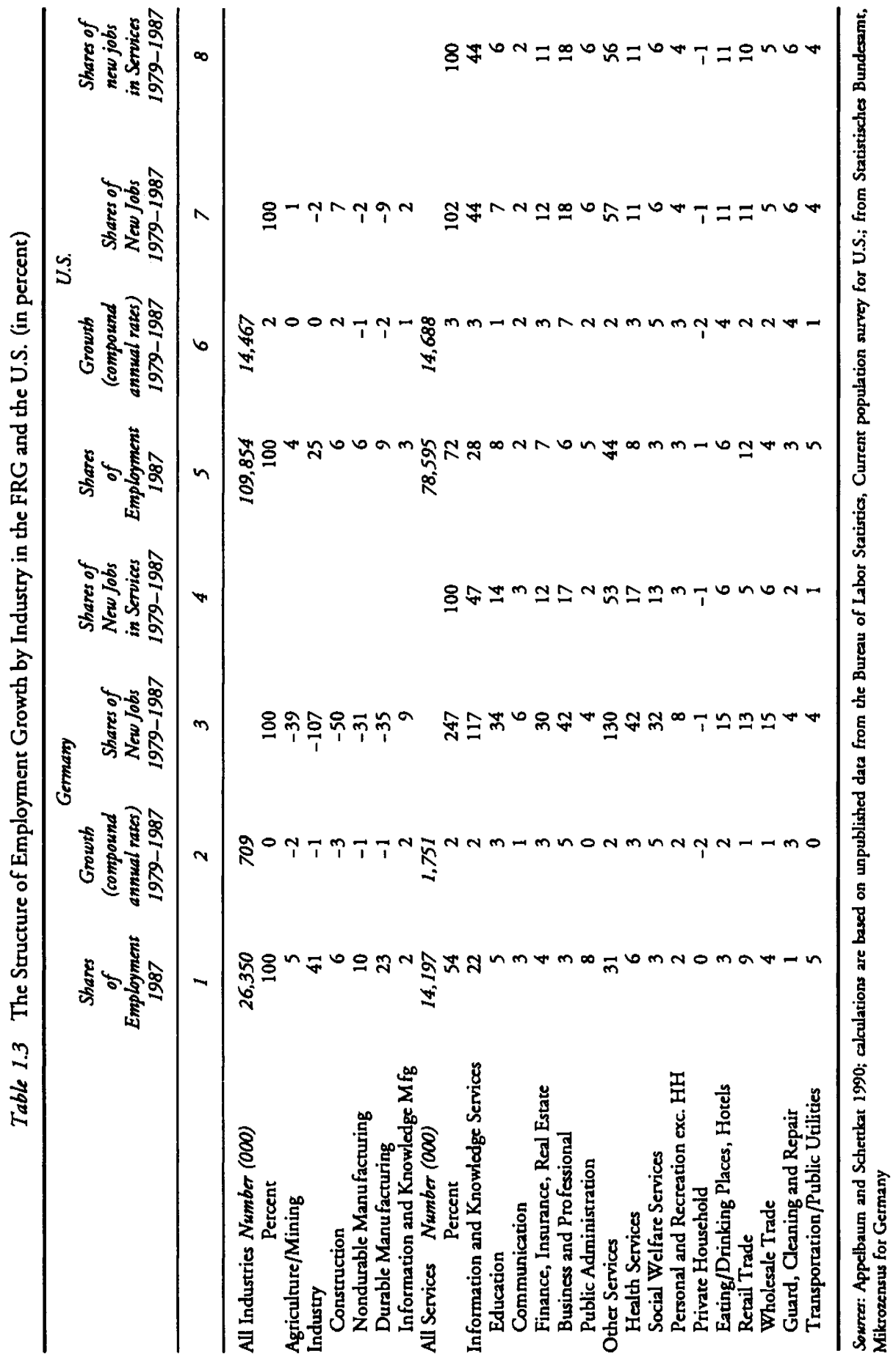


These arguments may be more important if the firm's environment is less stable and if products change quickly. Whereas detailed working rules are worth developing in the case of mass production, in small batch production this produces prohibitive costs. The production process relies on workers' cooperation. Too many unforeseen events happen which cannot be handled as with "flexible cooperation." That is to say, that quick responses to volatile product markets may require stable rather than unstable employment.

Often flexibility is equated with mobility that is numerical or external flexibility. In this sense it means the ability of firms to adjust their work force by hiring and firing. But flexibility can also mean skill flexibility and may be achieved withour any observed mobility in the labor market (Sengenberger 1987). The link between specific tasks and workers is an important difference between work organization in the U.S. and Germany. Whereas the task-worker link tends to be narrowly defined in the U.S., it is much weaker in Germany and this, together with a highly skilled work force, allows for internal adjustment as an alternative to external adjustments.

A similar case has been put forward with respect to human resource developments. Human capital theory suggests that investments in firm-specific human capital are causing higher employment stability because firms want to preserve these investments. This is perfectly good reasoning in a basically stable world where only unforeseen temporary shocks occur. In an uncertain world, however, the causation may be the other way round: Higher employment stability may be a necessary precondition for firms and employees to make specific human capital investments (Blinder and Krueger 1992; Buttler and Walwei 1992). Institutions that stabilize the economy and reduce uncertainty may be a precondition for certain investments and associated risks. The German apprenticeship system may be a good case, where firms invest in skills for young workers to a high degree (see Chapter 8). The closer the actual labor market would come to the idealized market model, the greater would be the risk for specific human capital investments, and the lower would be the propensity to carry these risks. The latter has led to investigations on whether regulations are functional or disfunctional, whether they are endogenous or exogenous; whether they are codified best practice or external constraints (Chapter 12).

Greater wage flexibility has been proposed as the key measure to adjust and to reallocate the labor force. Collectively negotiated wages in Europe supposedly destroyed the price-signal function of wages and thus slowed economic restructuring and led to stagnating employment. However, work on the impact of the degree of centralization in wage bargaining on employment performance (Freeman 1988a; Calmfors and Driffill 1988) showed that economies with centralized bargaining systems - which typically show low wage dispersion - experienced a comparable employment performance as economies with decentralized bargaining systems - which typically show wide wage dispersion. Economies positioned in the middle of a decentralized-centralized spectrum suffered most from low employment (Appelbaum and Schettkat 1993).

Linda Bell and Richard Freeman (1985) have pointed out that wage flexibility is often implicitly used as a synonym for downward wage flexibility. Undoubtedly, 
downward flexible wages will preserve jobs in declining industries, but the wage flexibility coin has two sides, it also means upward mobility of wages. Upward wage flexibility causes jobs in the more productive industries to expand less than those with lower upward wage flexibility. Bell and Freeman conclude that a certain degree of wage flexibility is necessary to ensure mobility of workers but that the net impact of wage flexibility needs to be calculated by subtracting job losses at the upper end of the productivity scale from job preservation at the lower end of the productivity scale. For the U.S., the authors conclude that employment expansion could have been greater with less flexible wages.

An important allegation against employment protection laws and subsequent costs is that these measures increase labor costs and thus lead to lower employment levels. They secure jobs for those employed, but by reducing the overall level of employment they exclude the unemployed: "It's a nice job if you can get one." Giuseppe Bertola (1992) argued that hiring and firing should not just be added to labor costs, as one would do in a static analysis, but that the dynamic effects of these costs need to be investigated. From his analysis he concludes that positive firing costs may well increase the level of employment. However, the impact of employment protection laws may be overestimated, because usually functional equivalents like short hours subsidies exist (Abraham and Houseman 1993 and Chapter 12 in this volume).

It is also argued that positive firing costs are necessary to achieve a social optimum. If employers would not carry firing costs, frequent dismissals may result. But dismissed workers cause costs for the society. They have less income to be spent, they rely on unemployment insurance benefits, etc. Positive firing costs endogenize at least parts of the social costs subsequent to dismissals into the decision-making process of the firm.

The intention of this short discussion is to show that the impact of institutions on economic performance is ambivalent. Institutions and regulations may limit the degrees of freedom of individual action, but they also reduce uncertainty (North 1990) and may create opportunities for action not available otherwise. In this sense, the decision is not one between regulation and nonregulation but rather one between different degrees and different forms of regulation.

\section{THE PLAN OF THE BOOK}

The functioning of labor markets in any industrialized economy is influenced by the regulation of the following areas:

1 work organization;

2 bargaining;

3 vocational training; and

4 employment adjustments (e.g. matching processes, employment protection).

The U.S. and Germany differ substantially in the ways these areas are regulated. For example, employment protection is well established in Germany but the U.S. can 
be characterized as "employment at will." This creates different costs and opportunities. Higher degrees of employment protection may slow employment adjustments to shocks. However, there are functional equivalents to hiring and firing, i.e. variations of average hours worked (see Chapter 12). Table 1.4 gives an overview of the main institutional characteristics of the U.S. and German economies.

The contributions of the volume are organized by the following sub-topics:

\section{Work Organization}

Using a large survey of establishments Paul Osterman analyzes the impact of new modes of work organization - like broad job definitions, team work, employee problem-solving groups, quality circles-on productivity. Made in America (Dertouzos et al. 1989) emphasized the importance of flexible work organization. Although there is a broad debate, it is not known how many firms undertake flexible work organization and which do not. Today, since skill requirements are not technologically determined, the questions asked are: How much training is there and why do some employers train more than others? In particular Paul Osterman's contribution seeks to provide an answer for the following set of questions:

1 What is the distribution of work organization practices across American firms?;

2 What determines which employers adopt the bundle of practices which are currently termed "high performance work practices?"; and

3 Are the training practices of establishments related to the nature of their work organization and other aspects of the establishment structure?

The Osterman survey establishes a positive association between high performance work systems and training efforts. For instance, the higher skilled the core jobs the more training is provided. Payment of efficiency wages is associated with higher levels of spending on training, while blue-collar workers are less likely to receive training. Also, a higher share of female core workers reduces training effort. The positive impact of flexible work organization on training holds only for more recently introduced innovations.

German-type works councils generate substantial interest in the U.S. because they seem to enable cooperative relationships between workers and management. They can serve as "a direct channel of communication between workers and management" (Freeman 1976) and they may be an efficient measure to create voice (Hirschman 1970). Bernd Frick and Dieter Sadowski give an overview of the literature on the economic impact of works councils in Germany and conclude that former studies were too ambitious in trying to establish a comprehensive measure for economic performance. The authors concentrate instead on a more specific measure, which is the impact of works council on personnel turnover. Works councils have a strong influence on the level of dismissals where they can object to them. The analysis, based on a large survey of establishments in Germany, shows that in establishments with a works council the turnover rate over a two-year period is 26 percent as compared to 38 percent in establishments without a works council. 


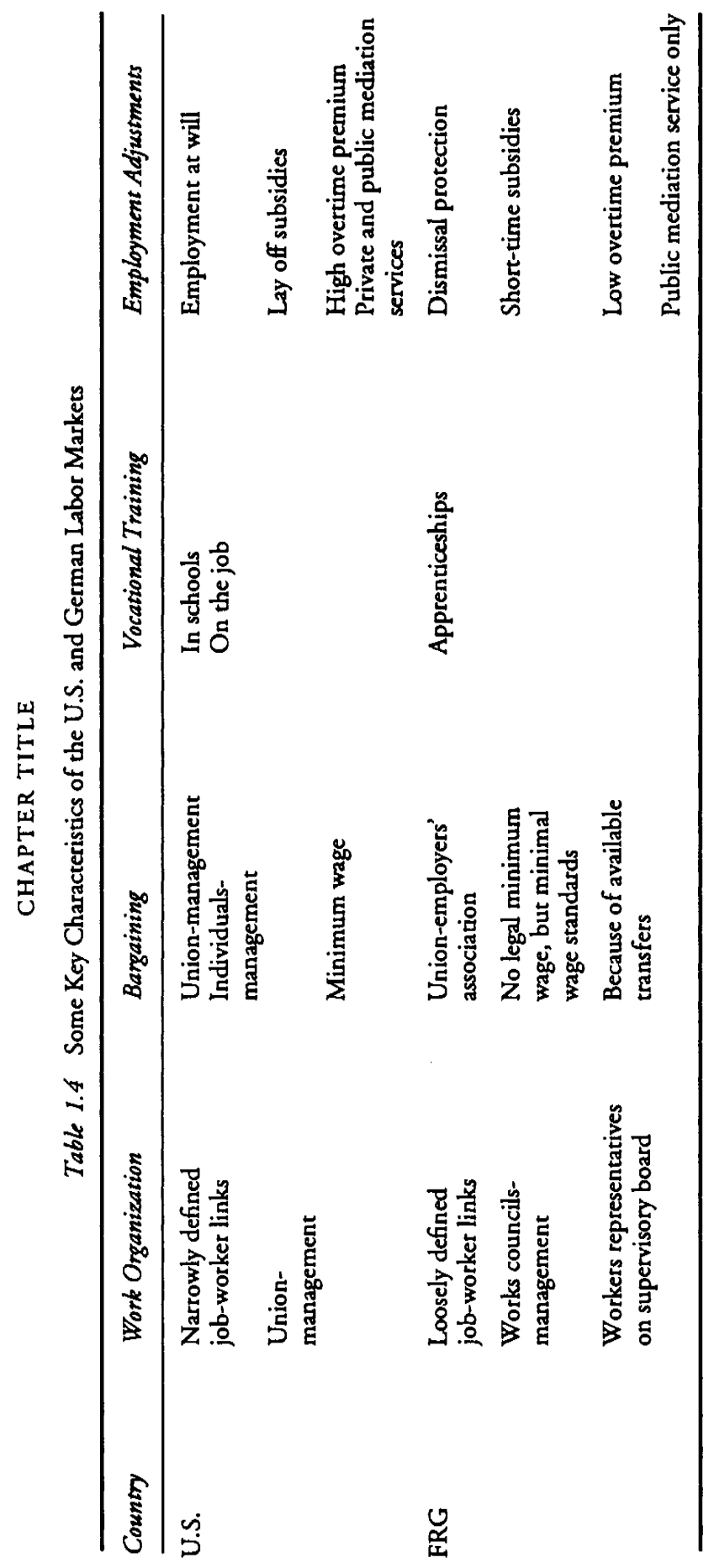




\section{F. BUTTLER, W. FRANZ, R. SCHETTKAT, D. SOSKICE}

Furthermore, works councils seem also to reduce quits but they seem not to have a negative impact on hiring rates. The works council's "voice" apparently fosters the economic survival of the firm in periods of contraction, thereby serving the interests of insiders. In expansionary periods, however, works councils tend to reduce the use of overtime work and thereby foster the recruitment of outsiders.

The conditions that might make one country's policy more or less transferable elsewhere are examined in the contribution by Daniel Hamermesh. He develops specific guidelines that can indicate when policy transfers are more likely to be successful. Hysteresis phenomena are considered to be a major obstacle against simple policy transfers. Hamermesh then compares policies restrictions on hours worked in Germany and the U.S. to study differences between these two countries. He emphasizes the quite neglected distinction between patterns of hours per week and hours per day. Unusual patterns of working hours are found for the U.S. where a significant fraction of the labor force either works long hours on few days, or, more commonly works relatively short hours over many days per week. Compared to the U.S., the German working hours pattern is much closer to a standard "forty-hours-five-day. workweek."

\section{Bargaining}

Why do Americans and Germans work different hours is the question asked by Linda Bell and Richard Freeman. Germans work shorter hours than Americans, who have, together with the Japanese, the longest hours of work. This, however, is a recent trend. The U.S. was among the earliest countries to establish the eighthour-five-day workweek and vacation time expanded considerably after World War II. In the 1950's and 1960's Americans worked considerably fewer hours than Germans and not until the 1980's did German hours worked fall below American hours worked. Based on microdata sets Bell and Freeman investigate the potential causes for this gap which include demographics, labor supply responses, institutions like strong unions and works councils, the legal framework, and preferences. Do individualized bargaining systems produce results which fit individuals' preferences better than collective bargaining systems?

Bell and Freeman find that although American workers work more hours than do workers in Germany and other European countries, they are still more likely to prefer additional hours than are German and other European workers. Furthermore, Germans are predisposed to further reductions in hours and more Germans than Americans are satisfied with the hours they actually work. The authors hypothesize that the difference partially reflects more subtle supply behavior in the form of responses to differences in labor market inequality, and present some suggestive evidence that people in settings with greater earnings inequality work more than those in settings with less inequality.

Interindustry wage differentials gained substantial attention in recent years (e.g. Krueger and Summers 1987; Dickens and Katz 1987) and macroeconomic studies emphasized on bargaining systems (e.g. Calmfors and Driffll 1988; 
Freeman 1988; Soskice 1990). The chapter by Lutz Bellmann and Joachim Möller analyzes wage levels and wage structures in Germany as compared to the U.S. The authors give an overview of wage setting in Germany, present results of previous studies on wage differentials and analyze wage differentials with a large individual data set which comprises all employees covered by social security insurance. Their study is comparable to the Krueger-Summers study of the U.S. but the analysis concentrates on German men working full-time in order to reduce the noise in the data.

Formal qualifications are more important for explanations of wage differentials in Germany than they are in the United States or in Sweden. That is, investments in human capital are rewarded in Germany where collective wage agreements in every industry classify certain qualificational groups. However, even when controlling for human capital variables "unexplained" interindustry wage differentials remain and these seem to have increased during the 1980's.

Following Weitzman's article (1983) the connection between pay schemes, employment and inflation is widely discussed. Blinder (1990) highlights the proposed relationship between pay schemes and labor productivity. Vivian Carstensen, Knut Gerlach and Olaf Hübler ask why few firms in Germany have introduced profitsharing schemes and they discuss the incentives as well as the impacts of profitsharing programs on firms' productivity trends. In their empirical investigation the authors find a great variety of profitsharing schemes in Germany. Larger firms are more likely to have a profitsharing scheme. Additionally, low competition and high market shares seem to foster such schemes. It may well be that profit sharing is used mainly in successful firms to motivate their work force. Due to the great variety of actual profitsharing schemes and the influence of nonpecuniary variables and participatory arrangements the relationship between profit sharing and productivity is not as clear cut as found in other studies.

\section{Vocational Training}

Why do German firms train is the main question Wolfgang Franz and David Soskice analyze. According to the standard Becker model employers should not invest in general training, but in Germany they do train apprentices in marketable skills although no sanctions or penalties exist for firms that do not train. The authors provide a short overview of the basic institutional features of the so-called dual educational system in Germany, which combines practical training in firms with more theoretical education in publicly financed schools. Based on a theoretical model, Franz and Soskice argue that large companies carry a net financial burden for the training of their apprentices. Although apprentices get high-quality training in marketable (general) skills, apprentices also pick up company-specific skills which would be costly if "outsiders" were hired. In smaller firms, by contrast, training costs seem to be overestimated. The authors suggest that apprentice training can be done at low or no net costs. 


\section{Employment Adjustments}

Robert Flanagan criticizes the standard labor market model in economics, which relates mobility in labor markets to variations in employment levels only. This is in stark contrast to the observed high mobility in labor markets (see Chapters 11 and 13 in this volume). Employer search and hiring behavior in economic models became a black box in the face of increasingly sophisticated formulations of how workers identified and accepted job offers. Flanagan's contribution provides a review and interpretation of the recent literature on how the structure of information in labor markets can influence the effect of institutional interventions in those markets. Policy intervention, such as targeted wage subsidies, advance notice of layoffs, restrictions on dismissals, and pay compression, are investigated. The extension of the basic model by signaling and screening allows Flanagan to show why group specific wage subsidies fail to produce the effects predicted by the standard model. Signaling effects can overcompensate cost reduction effects which are the main ingredient in the standard model.

Differences in the job mediation processes in the U.S., Germany, and other European countries are analyzed by Friedrich Buttler and Ulrich Walwei. In Germany, as in some other European countries, public employment services are in a monopoly position, in contrast to the institutional arrangements in the U.S. International comparisons show that a monopoly of public employment services does not necessarily open the way to high placements through these agencies. Public and private services can coexist but the coexistence can lead to substantial signaling effects. More effective employment services could reduce the unemployment duration and thus reduce the equilibrium rate of unemployment. The authors discuss possible consequences of public and private mediation agencies.

Job turnover, the gross creation and destruction of jobs, is distinct from labor turnover, which captures the conclusion and completion of employment contracts. Gross job creation and destruction is much higher than net variation as recent empirical studies have shown (e.g. Leonard 1987). Knut Gerlach and Joachim Wagner review the literature and present an empirical analysis for Germany and the U.S. Even in periods of minor net changes in jobs, gross variations are high and the latter varies much less over the business cycle. "The main point of all this is that labor demand is a more complex issue than is reflected by consideration of the neoclassical theory of production, as useful as that theory has been" (Hamermesh 1993). Do smaller firms grow faster than larger ones? Gerlach and Wagner investigate this question on the basis of a large sample of firms in Lower Saxony and found no such effect, which is in contrast to recent findings in American studies.

Susan Houseman and Katharine Abraham investigate the employment response to output variations in the U.S. and in Germany. Although dismissals are more costly in Germany than in the U.S., subsidized short-time work and lower overtime premiums in Germany allow for speed and volume adjustments in hours worked similar to those in the U.S. The difference between the two countries lies 
mainly in the means used to achieve the adjustments. In the U.S. average hours worked remain constant while the number of persons employed varies. In Germany average hours worked vary but the number of employed persons remains more stable. In the long run, however, in both economies the number of persons employed is reduced as a reaction to demand reductions. In a longitudinal analysis within Germany, Houseman and Abraham do not find evidence that the Works Constitution Act of 1972 - which actually strengthened workers' rights - as well as the Employment Promotion Act of 1985-which actually released restrictions on the conclusion of fixed-term employment contracts-affected the adjustment behavior of firms substantially.

A short overview of changes in regulations porentially affecting the functioning of labor markets in Germany is given in the contribution by Ronald Schettkat. He attributes the sharp decrease in overall labor market mobility in Germany to macroeconomic conditions rather than to changing incentive structure. The excess supply of labor has shortened the hiring chain, that is decreased in job-to-job mobility. Beveridge curves and matching functions for the U.S. and Germany are compared. He further argues that the analysis of matching processes should be based on flow data rather than on stock data which hide the actual dynamics of the labor market. The author concludes that empirical evidence suggests that the functioning of labor markets in Germany did not deteriorate over time.

\section{REFERENCES}

Abraham, K. G. and Houseman, S. N. (1993) "Job Security in America, Lessons from Germany," Washington: Brookings Institution.

Appelbaum, E. and Schettkat, R. (1990) "Determinants of Employment Developments: A Comparison of the United States and the Federal German Economies," Labour and Sociery 15: 13-31.

— (1993) "Economic Development in Industrialized Economies: Explaining Common and Diverging Trends," discussion papers FS I 313, Berlin: Wissenschaftszentrum.

Bell, L. A. and Freeman, R. B. (1985) "Does a Flexible Wage Structure Increase Employment?: The U.S. Experience," NBER Working Paper, No. 1604, Cambridge, MA: National Bureau of Economic Research.

Chapter 5 in this volume.

Bellmann, L. and Möller, J., Chapter 6 in this volume.

Bertola, G. (1992) "Labor Turnover Costs and Average Labor Demand," Journal of Labor Economics 10, 4: 389-411.

Blank, R. M. and Freeman, R. B. (1994) "Evaluating the Connection Between Social Protection and Economic Flexibility," in R. Blank, (ed.) Social Protection Versus Economic Flexibility: Is There a Trade-Off?, Chicago: University of Chicago Press.

Blinder, A. S. (ed.) (1990) "Paying for Productivity," Washington: Brookings Institution.

Blinder, A. S. and Krueger, A. B. (1992) "International Differences in Labor Turnover: A Comparative Study with Emphasis on the U. S. and Japan," mimeo, Princeton: Princeton University.

Buttler, F. (1987) "Labour Market Flexibility by Deregulation? The Case of the Federal Republic of Germany," Labour and Society 12: 29-35.

Buttler, F. and Walwei, U. (1992) "The Employment Contract: Cooperation Requires Stability," paper presented at the SASE Conference in Irvine, California, March 1992. 
Chapter 10 in this volume.

Calmfors, L. and Driffill, J. (1988) "Bargaining Structure, Corporatism and Macroeconomic Performance," Economic Policy 6, April: 14-61.

Carstensen, V., Gerlach, K. and Hübler, O., Chapter 7 in this volume.

Coase, R. (1937) "The Nature of the Firm," Economica: 386-405.

David, P. (1975) Technical Choice and Economic Growth, London and New York: Cambridge University Press.

Dertouzous, M., Lester, R. and Solow, R. (1989) Made in America, Cambridge, MA: MIT Press.

Dickens, W. T. and Katz, L. F. (1987) "Inter-Industry Wage Differences and Industry Characteristics," in: K. Lang and J. S. Leonard, (eds.), Unemployment and the Structure of Labor Markets, New York: Basil Blackwell.

Donges, J. B. (1992) "Deregulierung am Arbeitsmarkt und Beschäftigung," Tübingen: Mohr 1992.

Finegold, D. and Soskice, D. (1989) “Britain's Failure to Train: Explanation and Possible Strategies," Oxford Review of Economic Policy 4, 3: 21-53.

Flanagan, R., Chapter 9 in this volume.

Franz, W. (1991) "Match and Mismatch on the German Labour Market," in PadoaSchioppa (ed.), Mismatch and Labour Mobility, Cambridge: Cambridge University Press.

Franz, W. and Gordon, R. J. (1993) "German and American Wage and Price Dynamics: Differences and Common Theme," European Economic Review 37: 719-745.

Franz, W. and Soskice, D., Chapter 8 in this volume.

Freeman, R. B. (1976) "Individual Mobility and Union Voice in the Labor Market," American Economic Review 66: 361-268.

- (1988a) "Labor Market Institutions and Economic Performance," Economic Policy 6: 63-80.

- (1988b) "Evaluating the European View that the United States Has No Unemployment Problem," American Economic Review 78: 294-299.

Freemann, C. (1989) "National and Regional Capabilities for Innovation and the Role of Government," Paper presented at the Government of Finland and OECD Conference on Technological Change as a Social Process, Helsinki, December.

Frick, B. and Sadowski, D., Chapter 3 in this volume.

Gerlach, K. and Wagner, J., Chapter 11 in this volume.

Giersch, H. (1985) "Eurosclerosis," Kiel Discussion Paper 112, Kiel: Institut für Weltwirtschaft.

Gordon, R. J. (1990a) "What is New-Keynesian Economics?," Journal of Economic Literature 28: 1115-1171.

(1990b) "U.S. Inflation, Labor's Share, and the Natural Rate of Unemployment," in

H. König, (ed.), Economics and Wage Determination, Berlin: Springer.

Hamermesh, D. (1993) Labor Demand, Princeton: Princeton University Press.

Chapter 4 in this volume.

Hirschman, A. O. (1970) Exit, Voice, Loyalty, Cambridge, MA: Harvard University Press.

Houseman, S. and Abraham, K., Chapter 12 in this volume.

Krueger, A. B. and Summers, L. H. (1987) "Reflections on the Inter-Industry Wage Structure," in K. Lang and J. S. Leonard, (eds), Unemployment and the Structure of Labor Markets, New York: Basil Blackwell.

Leonard, J. S. (1987) "In the Wrong Place at the Wrong Time," in K. Lang and J. S. Leonard (eds), Unemployment and the Structure of Labor Markets, New York: Basil Blackwell.

Nelson, R. R. and Winter, S. G. (1982) An Evolutionary Theory of Economic Change, Cambridge, MA: Harvard University Press.

North, D. C. (1990) Institutions, Institutional Change and Economic Performance, Cambridge: Cambridge University Press. 
Osterman, P., Chapter 2 in this volume.

Reich, R. (1993) speech.

Rosenberg, N. (1982) Inside the Black Box, Cambridge: Cambridge University Press.

Schettkat, R. (1989) Innovation und Arbeitsmarktdynamik, Berlin and New York: De Gruyter.

- (1992) The Labor Market Dynamics of Economic Restructuring, The United States and Germany in Transition, New York: Praeger Publishers.

Chapter 13 in this volume.

Sengenberger, W. (1987) Struktur und Funktionsweise von Arbeitsmärkten, Frankfurt and New York: Campus.

Soskice, D. (1993) "Social Skills from Mass Higher Education: Rethinking the CompanyBased Initial Training Paradigm," Oxford Review of Economic Policy 9, 3: 1-13.

Ulman, L., Eichengreen, B. and Dickens, W. (eds) (1993) Labor and an Integrated Europe, Washington: Brookings Institution.

Weitzman, M. (1983) "Some Macroeconomic Implications of Alternative Compensation Systems," Economic Journal 93: 763-783.

Williamson, O., Wachter, M. and Harris, J. (1975) "Understanding the employment relation: the analysis of idiosyncratic exchange," The Bell Journal of Economics: 250-278. 